Portland State University

PDXScholar

Summer 1981

\title{
Characterization of gram-positive bacterial isolates from burn victims
}

Trisha A. Hannan

Portland State University

Follow this and additional works at: https://pdxscholar.library.pdx.edu/open_access_etds

Part of the Bacteriology Commons, and the Biology Commons

Let us know how access to this document benefits you.

Recommended Citation

Hannan, Trisha A., "Characterization of gram-positive bacterial isolates from burn victims" (1981). Dissertations and Theses. Paper 3057.

https://doi.org/10.15760/etd.3053

This Thesis is brought to you for free and open access. It has been accepted for inclusion in Dissertations and Theses by an authorized administrator of PDXScholar. Please contact us if we can make this document more accessible: pdxscholar@pdx.edu. 
AN ABSTRACT OF THE THESIS of Trisha A. Hannan for the Master of Science in Biology presented July 14, 1981.

Title: Characterization of Gram-Positive Bacterial Isolates from Burn Victims

APPROVED BY MEMBERS OF THE THESIS COMMITTEE:

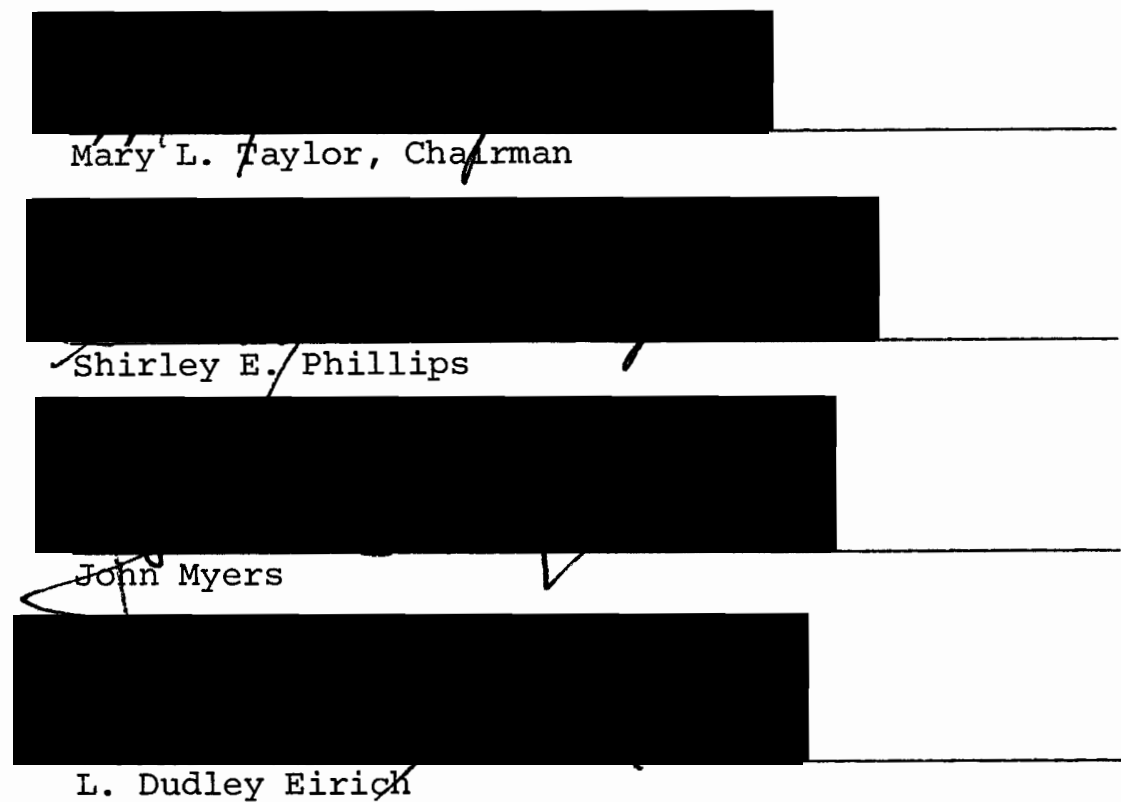

Streptococcus and Staphylococcus were collected from patients hospitalized at the Oregon Burn Center, Emanuel Hospital, Portland, Oregon, between October 27, 1980 and January 1, 1981. Forty-five isolates of Staphylococcus and twenty-one isolates of streptococcus, Lancefield Group D, were included in the investigation.

The objectives of the investigation were: (i) to identify to the species level all isolates, (ii) to determine their susceptibility 
to antimicrobial agents, (iii) to test the organisms over time for increasing resistance to silver, (iv) to determine, if present, a bacterium harbored within the burn. unit (nosocomial bacterium), and (v) to determine any recognizable pattern of successive bacterial colonization which occurred in hospitalized patients.

Biochemical tests were conducted on each isolate to determine species differentiation. Antibiotic susceptibility tests were performed on all isolates. Susceptibility tests to the inorganic salts of arsenate, arsenite and mercury were performed on all species of Staphylococcus. The minimal inhibitory concentration (MIC) of silver nitrate was determined for all isolates.

Species of group D streptococci identified were: streptococcus faecalis, streptococcus faecium and Streptococcus faecium var. casseliflavus. Species of staphylococcus identified were: Staphylococcus aureus, Staphylococcus cohnii, Staphylococcus epidermidis, Staphylococcus haemolyticus, staphylococcus hominis, staphylococcus simulans and Staphylococcus warneri.

Antibiotic susceptibility tests yielded typically speciesspecifiç results. The MICs of silver nitrate ranged from $1.25 \mu \mathrm{g} / \mathrm{ml}$ to $5.0 \mu \mathrm{g} / \mathrm{ml}$. The MIC data showed a species-specific susceptibility pattern rather than one of increasing resistance. Analysis of all isolates yielded no common, persistent organism within the burn unit. Although $S$. aureus isolates were the most tenacious organisms, no pattern of successive bacterial colonization was indicated by the data collected. 
CHARACTERIZATION OF GRAM-POSITIVE BACTERIAL

ISOLATES FROM BURN VICTIMS

by

TRISHA A. HANNAN

A thesis submitted in partial fulfillment of the requirements for the degree of

\author{
MASTER OF SCIENCE \\ in \\ BIOLOGY
}

Portland State University

1981 
TO THE OFFICE OF GRADUATE STUDIES AND RESEARCH:

The members of the Committee approve the thesis of Trisha A. Hannan presented July 14, 1981.

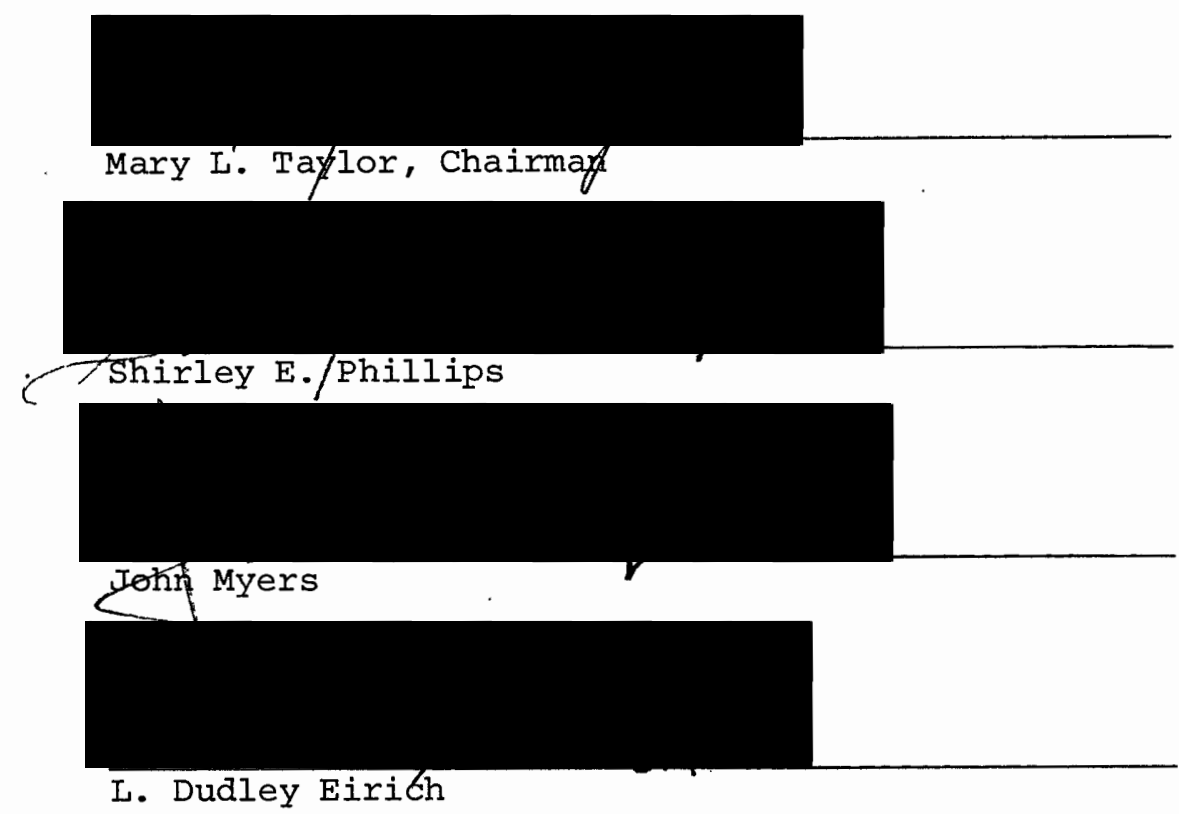

APPROVED :

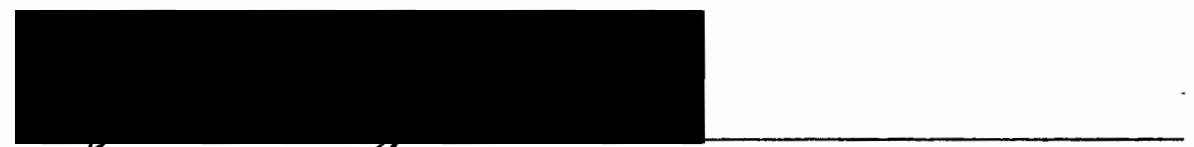

w. H. Taylor, Heza, Department of Biology 


\section{ACKNOWLEDGEMENTS}

The author would like to thank all committee members for their help, and my friends and parents for putting up with me throughout this vigil.

Special thanks to Dr. Shirley Phillips and the Emanuel Hospital Microbiology Laboratory for supplying the isolates, antibiotic discs, petri dishes, numerous chemicals, various carbohydrates, etc.

Also, thanks to st. Vincent's Hospital for supplying the replicator apparatus in part of the investigation. 
TABLE OF CONTENTS

PAGE

ACKNOWTEDGMENTS

LIST OF TABLES . . . . . . . . . . . . . . . . . . . . . . vi v v

CHAPTER

I INTRODUCTION . . . . . . . . . . . . . . . . 1

Burn Trauma ................ . . . 1

Genus streptococcus ............. . 4

Genus Staphylococcus ............ 5

Description of the Investigation . . . . . . 6

II METHODS AND MATERIALS . . . . . . . . . . . 7

Biochemical Tests for Differentiation of Isolates

of group D streptococcus . . . . . . . .

Catalase

Tetrazolium Reduction

Potassium Tellurite

Temperature Tolerance

Growth in 6.5 Percent Sodium Chloride

Other Tests

Biochemical Tests for Differentiation of Isolates of Staphylococcus . . . . . . . . . .

Catalase

Glycerol Fermentation

Lysostaphin

Phosphatase Production

Nitrate Reduction

Vogues-Proskauer Test

Carbohydrate Fermentation

Antibiotic Susceptibility Tests . . . . . . . 
Disc Diffusion (Agar)

Antimicrobial Agent Susceptibility . . . . . .

Arsenate, Arsenite and Mercury

Silver Susceptibility, Agar-Dilution

Silver Susceptibility (MIC), Broth-Dilution

Analysis of the Data of Species Differentiation .

Chemicals . . . . . . . . . . . . 12

III RESULTS AND DISCUSSION . . . . . . . . . . . 14

Species of Streptococcus . . . . . . . . . . 14

Individual Analysis of the Isolates of

Streptococcus, Lancefield Group D . . . . .

Streptococcus faecalis

Streptococcus faecium

streptococcus faecium var. casseliflavus

Species of Staphylococcus . . . . . . . . . 22

Individual Analysis of the Isolates of

Staphylococcus . . . . . . . . . 30

Staphylococcus aureus

Staphylococcus cohnii

Staphylococcus epidermidis

Staphylococcus haemolyticus

staphylococcus hominis

staphylococcus simulans

Staphylococcus warneri

Silver Susceptibility, Agar-Dilution . . . . . 31

Bacterial Succession . . . . . . . . 32

Limitations of the Investigation . . . . . 36

IV SUGGESTIONS FOR FURTHER RESEARCH . . . . . . . . . . 37

V SUMMARY . . . . . . . . . . . . . . . . 38 
I Topical Agents . . . . . . . . . . . . . . .

II Reactions Useful in Characterization of Species of Streptococcus, Lancefield Group D . . . . . . . .

III Reactions of Identified Species of Streptococcus, Lancefield Group D . . . . . . . . . . . .

IV Antibiotic Susceptibility of Isolates of Streptococcus, Lancefield Group D . . . . . . . . . . . . 18

V Minimum Inhibitory Concentrations of Silver Nitrate (Species of Streptococcus; Lancefield Group D). . . 20

VI Reactions Useful in Characterization of Species of staphylococcus . . . . . . . . . . . . 23

VII Reactions of Identified Species of Staphylococcus . • . 24 VII Antibiotic Susceptibility of Species of Staphylococcus . . . . . . . . . . . . .

IX Susceptibility of Species of Staphylococcus to Inorganic Salts of Arsenate, Arsenite and Mercury . . . . . 28

$\mathrm{X}$ Minimum Inhibitory Concentrations of Silver Nitrate (Species of Staphylococcus) . . . . . . . . . 29

XI Bacteria. Isolated from Patients as a First Culture . . . 33 XII Sequential Isolation of Bacteria (One Patient) . . . . 35 
CHAPTER I

INTRODUCTION

\section{Burn Trauma}

Thermal burns are among the most common, most extensive and most lethal forms of trauma (1). Persons sustaining severe burns manifest numerous physiological and biochemical alterations.

The vascular response to burn injury is marked. Increased vascular permeability, as a result of the release of vasoactive substances, leads to edema and the formation of blisters $(2,3)$. Substantial losses of fluid and electrolytes through the burn wound may result. in metabolic acidosis $(4,5)$. Thromboplastins released from damaged tissues cause aggregations of erythrocytes (6) and thrombocytes (5).

Direct upper respiratory tract damage from inhalation of superheated air and smoke leads to head and neck edema. Days later, decreased diffusion of oxygen across the alveolar membrane may occur, and death may result.

Evaporative water loss through eschar (inert and denatured biological-matter) results in increased caloric expenditure to maintain thermal equilibrium (7). Excessive protein catabolism as a result of the subsequent energy demand may lead to renal hypertrophy, hyperplasia and semi-permanent enlargement of the kidneys (8). Thermal injury also stimulates the sympatho-adrenal medullary 
system, resulting in an increase in blood levels and urinary output of adrenalin and noradrenalin (9).

The intact epidermis constitutes an effective barrier to the ingress of bacteria from the environment. Burning the skin results in a distinct impairment of this role (1). The impaired condition persists until the eschar is totally separated and granulation tissue formation complete (10). A compromised immune system due to local destruction of phagocytic cells in the burn wound (11, 12) also renders the burn victim susceptible to bacterial invasion and colonization. Thus, infection is a major hazard to life after burn trauma, in which the burn wound plays a primary role $(11,13,14)$. Bacterial colonization of the burn wound is inescapable and as bacteria begin invading the viable, unburned, tissue surrounding the wound, septicemia may result. The indigenous flora of the skin are initially recovered (i.e., staphylococcus epidermidis and other coagulase-negative species of Staphylococcus); however, colonization of the wound by pathogenic species (e.g., staphylocaccus aureus from nasal passages) will occur within as little as sixteen hours unless prompt burn wound bacteriostasis is begun and maintained (1). Bacteria can reach concentrations of $10^{6}-10^{7}$ organisms per gram of burn tissue before overt signs and symptoms of systemic sepsis are evident (15).

Thus in addition to early life support care, medical therapy includes the topical application of an antimicrobial substance aimed at preventing burn wound sepsis (16). Table I lists and describes the topical agents in use at the Oregon Burn Center (OBC). The 


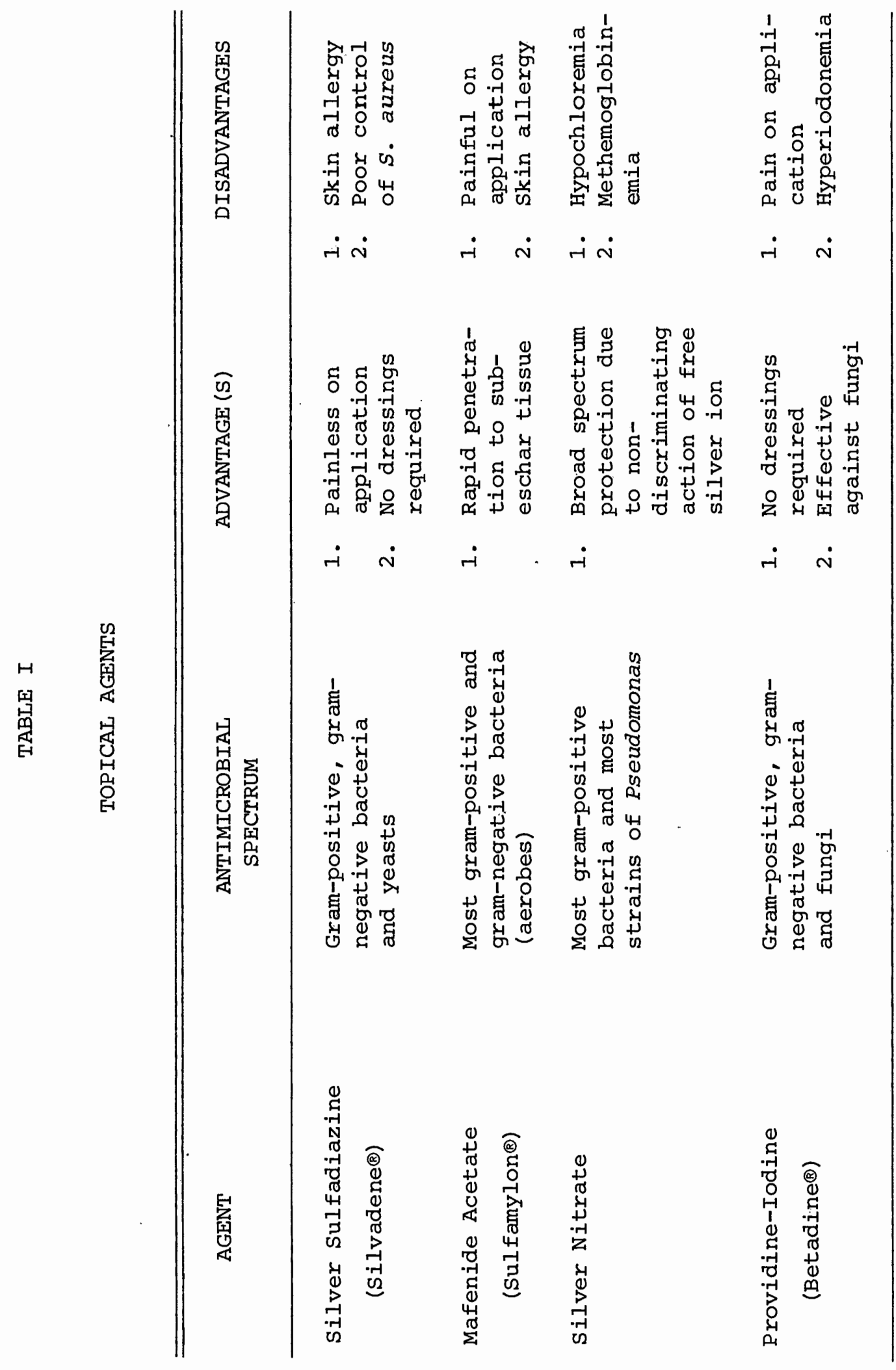


broad-spectrum activity of topical therapy is necessary as grampositive, and gram-negative species of bacteria (both aerobic and anaerobic), and fungi may flourish on, in and below the eschar.

Isolation and identification of the organisms present in the burn victim is of utmost importance. Bacterïologic monitering of the burn wound takes into account several parameters: type, number, location and antibiotic sensitivity of the bacteria (17).

The following investigation was performed to elucidate the characteristics of the species of Staphylococcus and Group D Streptococcus isolated from patients hospitalized in the OBC.

\section{Genus Streptococcus}

The streptococci are a heterogeneous group of organisms in the family streptococcaceae. The organisms are gram-positive, catalasenegative, non-spore forming cocci. They possess a fermentative type of metabolism and are classified as facultative anaerobes (18, 19, $20,21)$

The streptococci can be grouped serologically, commonly referred to as the Lancefield groups, designated A - V. The organisms of Lancefield Group D contain a soluble polysaccharide (a teichoic acid) present between the cell wall and the cell membrane $(18,19$, $20,22)$

Members of the group D streptococci are differentiated by characteristic biochemical patterns which are used for speciation.

The group.D streptococci are normal fecal flora, but can frequently colonize extra-intestinal surfaces (22). Although isolation' of group D streptococci from sites other than feces does not in 
itself indicate a current infection, organisms found in a burn wound, or in the blood stream, increase the chance for development of septicemia, endocarditis and urinary tract infections.

Streptococcus faecalis (and varieties) and streptococcus faecium (and varieties) are the strains most often associated with streptococcal infection $(22,23,24)$. These species also are usually quite resistant to antimicrobial agents $(25,26)$, so eradication of these organisms can be difficult.

\section{Genus Staphylococcus}

The staphylococci are a heterogeneous group of organisms in the family Micrococcaceae. The organisms are: gram-positive, catalasepositive, non-spore forming cocci. They are aerobic organisms and have both respiratory and fermentative capabilities. Human species of Staphylococcus include Staphylococcus aureus, S. capitis, S. cohnii, S. epidermidis, S. haemolyticus, S. hominis, S. saprophyticus, S. simulans, S. warneri and S. xylosus (21a, 27, 28, 29).

Historically, the coagulase-positive species of $S$. aureus has been regarded as an opportunistic pathogen, whereas the coagulasenegative species have been generally regarded as non-pathogens (28). However, [Staphylococcus epidermidis can produce a number of virulence factors such as deoxyribonuclease and hemolysins which aid in pathogenicity (33)] today it is well documented that coagulase-negative species of Staphylococci can be associated with disease $(30,31,32)$, and their resistance to many antibiatics makes it important that the isolates be accurately identified (33). 
Identification of the species of Staphylococci can be accomplished by the results of a series of physiological and biochemical tests.

Description of the Investigation

The identification of the species of both the group D streptococci and staphylococci is important with respect to hospital epidemiology. Biochemical parameters can be used to biotype (fingerprint) each bacterial strain isolated. These biotypes then can be used for determination of the presence of a nosocomial (resident) bacterium that infects, or colonizes, each patient in the unit.

Species of both Staphylococcus and Streptococcus can persist on inanimate objects outside the body, such as dust or surfaces in rooms. These environmental reservoirs (23) are one possible source of nosocomial bacteria, as is cross-contamination of patients via personnel working within the burn unit.

The objectives of the investigation were to: (i) identify all gram-positive bacterial isolates, (ii) determine their susceptibility to antibiotics and antimicrobial agents, (iii) test the organisms, isolated over time, for increasing resistance to silver ion as a result of selective pressure as a result of the topical use of Silvadene ${ }^{\circledR}$ (silver sulfadiazine), (iv) determine if a nosocomial bacterium was being transmitted from patient to patient, and ( $v$ ) determine if a pattern of successive bacterial colonization occurred in each patient. 


\section{CHAPTER II}

\section{METHODS AND MATERIALS}

The bacterial strains used in this investigation were isolates from eighteen patients hospitalized in the $O B C$, Emanuel Hospital, Portland, Oregon. Cultures were received from the Emanuel Hospital Microbiology Laboratory on agar slants. Stock cultures of all organisms were maintained in a sterile 50 percent glycerol - 50 percent $0.01 \mathrm{M}$ phosphate buffer (pH $7.0-7.2)$ suspension at $-20^{\circ}$ Centigrade. Control organisms included S. aureus (ATCC 29213, ATCC 25923), S. epidermidis (ATCC 14990) and S. faecalis (ATCC 29212).

All organisms were characterized by routine biochemical procedures and antimicrobial agent susceptibility tests as described below.

\section{BIOCHEMICAL TESTS FOR DIFFERENTIATION OF ISOLATES OF GROUP D STREPTOCOCCUS}

\section{Catalase}

Isolates were tested for the ability to produce catalase. An individual colony from an overnight plate culture was placed on a clean microscope slide, one drop of 3 percent hydrogen peroxide $\left(\mathrm{H}_{2} \mathrm{O}_{2}\right)$ added, and observed.for evolution of bubbles. The test was considered negative if no immediate bubbling occurred (21b). 
Tetrazolium Reduction

The ability of each isolate to, reduce 2.3.5-Triphenyltetrazolium chloride (Sigma) to the insoluble compound formazan was assayed by using a modification of the method of Barnes (34).

\section{Potassium Tellurite}

The ability of each isolate to initiate growth in the presence of 0.04 percent potassium tellurite was determined by adding Chapman Tellurite Solution (DifCo) to 5 milliliters Brain Heart Infusion broth (BHI, BBL) to a final concentration of 0.04 percent. Tubes were incubated at $37^{\circ}$ Centigrade. Tests were considered negative if no black precipitate was evident within seventy-two hours.

\section{Temperature Tolerance}

The ability of each isolate to initiate growth at $10^{\circ}$ Centigrade and $45^{\circ}$ Centigrade was tested in tubes containing 3 milliliters BHI. Tests were considered negative if no turbidity was visible within seventy-two hours at the stated temperature.

\section{Growth in 6.5 Percent Sodium Chloride}

The ability of each isolate to initiate-growth in 6.5 percent sodium chloride ( $\mathrm{NaCl}$ ) was performed in tubes containing 3 milliliters BHI with the appropriate concentration of NaCl added. Tubes were incubated at $37^{\circ}$ Centigrade and tests were considered negative if turbidity was not evident within forty-eight hours.

\section{Other Tests}

The ability of each isolate to produce acid in litmus milk 
(Difco), ability to hydrolyze gelatin (Difco) and starch (Mallinkrodt) and carbohydrate fermentation tests were conducted using the methods of Facklam (18). Carbohydrates tested were lactose, sorbitol, sucrose, mannitol and arabinose.

\section{BIOCHEMICAL TESTS FOR DIFFERENTIATION OF ISOLATES OF STAPHYLOCOCCUS}

\section{Catalase}

Isolates were tested for the ability to produce catalase. An individual colony from an overnight plate culture was placed on a clean microscope slide, one drop of 3 percent $\mathrm{H}_{2} \mathrm{O}_{2}$ added, and observed for evolution of bubbles. The test was considered positive if immediate bubbling occurred (21b).

\section{Glycerol Fermentation}

Ability to ferment glycerol in the presence of 0.01 percent erythromycin (Sigma) was tested to eliminate any species of Micrococcus which may have been present as a contaminant (35).

\section{Lysostaphin}

Isolates of Staphylococcus were screened for susceptibility or resistance to lysostaphin at a concentration of $50 \mu \mathrm{g} / \mathrm{ml}$ in $\mathrm{P}$ Agar (28, 36). (P Agar: Peptone, 10 grams; Yeast Extract, 5 grams; NaCl, 5 grams; Glucose, 1 gram; Agar, 15 grams; and water, 1 litre.)

\section{Phosphatase Production}

All isolates of Staphylococcus were tested for the ability to produce phosphatase enzyme, as described by MacFaddin (21c). The 
indicator used was 0.05 percent phenolphthalein diphosphate (Mallinkrodt).

Nitrate Reduction

The ability of each coagulase-negative isolate to reduce potassium nitrate to nitrite or nitrogen gas was determined in Nitrate Broth (DifCo) (21d).

\section{Vogues-Proskauer Test}

Coagulase-negative strains of Staphylococcus were tested for the ability to produce a neutral end product, acetoin, from glucose fermentation (21e).

\section{Carbohydrate Fermentation}

The ability of each isolate to utilize and ferment various carbohydrates was tested (28). Coagulase-positive strains were tested for fermentation of mannitol, galactose, trehalose, ribose and xylose. In addition to the aforementioned carbohydrates, coagulase-negative strains were tested for utilization of sucrose, lactose, maltose and mannose.

\section{ANTIBIOTIC SUSCEPTIBILITY TESTS}

\section{Disc Diffusion (Agar)}

Innocula for the antibiotic susceptibility tests were derived from the stock glycerol-phosphate suspensions and grown overnight in 5 milliliters BHI at $37^{\circ}$ Centigrade (37). Methods employed were those recommended by the National Committee for Clinical Laboratory standards (38). Innoculated plates with antibiotic discs (BBL) were 
incubated at $37^{\circ}$ Centigrade and zone sizes of inhibition measured after twenty-four hours. Species of Staphylococcus were tested for susceptibility to cefamandole; penicillin, cephalothin, tetracycline, methicillin, cefoxitin, novobiocin, erythromycin and clindamycin. Species of Streptococcus were tested for susceptibility to the above mentioned antibiotics as well as tobramycin, carbenicillin, nitrofurantoin, gentamicin and amikacin.

\section{ANTIMICROBIAI AGENT SUSCEPTIBIIITY}

\section{Arsenate, Arsenite and Mercury}

Species of Staphylococcus were tested for susceptibility to disodium arsenate $(0.1 \mathrm{M})$, sodium arsenite $(1.0 \mathrm{M})$ and mercuric chloride $\left(10^{-3} \mathrm{M}\right)$. The tests were performed according to the methods of Novick and Roth (39), utilizing Mueller Hinton Agar (MHA, Difco). Zone sizes. of inhibition were measured after twenty-four hours incubation.at $37^{\circ}$ Centigrade and interpreted as follows: arsenate susceptibility, 11 millimeters and greater; arsenite susceptibility, 10 millimeters and greater; and mercury susceptibility, 9 millimeters and greater.

\section{Silver Susceptibility, Agar Dilution}

Using sterile technique, silver nitrate $\left(\mathrm{AgNO}_{3}\right)$ in two-fold dilutions (concentrations ranged from $156 \mu \mathrm{g} / \mathrm{ml}$ to $0.01 \mu \mathrm{g} / \mathrm{ml}$ ) was pipetted into a nutrient agar [1 percent Tryptone (Difco), 0.5 percent Glucose, 2 percent Agar]. Medium containing each concentration of . $\mathrm{AgNO}_{3}$ was dispensed into 15 x 100 millimeter plastic petri dishes (40). Cultures were innoculated onto the agar using a replicator apparatus similar to the one described by steers, et al. $(41,42)$. Plates were 
incubated at $37^{\circ}$ Centigrade for twenty-four hours and observed for visible growth.

\section{Silver Susceptibility (MIC), Broth-Dilution}

Using sterile technique, silver nitrate, in two-fold dilutions, was pipetted into Mueller Hinton Broth (MHB, Difco). Final concentrations of $\mathrm{AgNO}_{3}$ ranged from $10 \mu \mathrm{g} / \mathrm{ml}$ to $1.25 \mu \mathrm{g} / \mathrm{ml}$. Two milliliters of the $\mathrm{AgNO}_{3}-\mathrm{MHB}$ were pipetted into sterile tubes, and inoculated with $5 \times 10^{5}$ bacteria/ml. Turbidity was checked after twenty-four hours incubation at $37^{\circ}$ Centigrade (43). The lowest concentration in each series showing no visible turbidity was reported as the minimum inhibitory concentration (MIC) (44).

ANALYSIS OF THE DATA OF SPECIES DIFFERENTIATION

Individual combinations of each isolates' response to all agents tested (biochemical and antimicrobial) were tabulated and assigned a "type number", similar to the methods described by Iapage and willcox (45). By comparison of "type numbers" within the species, patient-bypatient analysis was also accomplished. The criteria used in defining a nosocomial (resident) bacterium were: exact biochemical phenotypes and exact antimicrobial agent susceptibility patterns. These "exact" bacteria must also have been recovered from at least six patients (33 percent of the sample).

\section{CHEMICAIS}

All carbohydrates were of reagent grade. Mannose, trehalose and ribose were obtained from Sigma. All others were obtained from 
Mallinkrodt, as was the NaCl. Lysostaphin (Lot No. 40F-0532) was obtained from Sigma. Silver nitrate, from Mallinkrodt, was of analytical reagent quality. 


\section{RESULTS AND DISCUSSION}

\section{Species of Streptococcus}

Using the criteria shown in Table II, isolates of group D streptococci were differentiated into three biochemically distinct species, namely: S. faecalis, S. faecium and S. faecium var. casseliflavus. Table III shows the reactions of the aforementioned species on a cumulative percentage basis. In the OBC these isolates were found in the following percentage distribution: $S$. faecalis, 38 percent; S. faecium, 38 percent; and S. faecium var. casseliflavus, 24 percent. These figures are of interest by virtue of the fact that of the group D. streptococci, $S$. faecalis is the species most often isolated in infection $(18,22,46)$. As seen above, $S$. faecium and S. faecium var. Casseliflavus comprised 62 percent of the isolates of group D streptococci. All twenty-one strains of group D streptococci were isolated from six patients (33 percent of the sample) and were recovered only between the period from November 13, 1980 to December $12,1980$.

Streptococcus faecalis was easily differentiated from $S$. faecium by the reactions in tetrazolium, tellurite, sorbitol and arabinose. Streptococcus faecium was differentiated from $S$. faecium var. casseliflavus by the reactions in tellurite and tetrazolium. The fourteen tests employed proved satisfactory for determining the species of the 


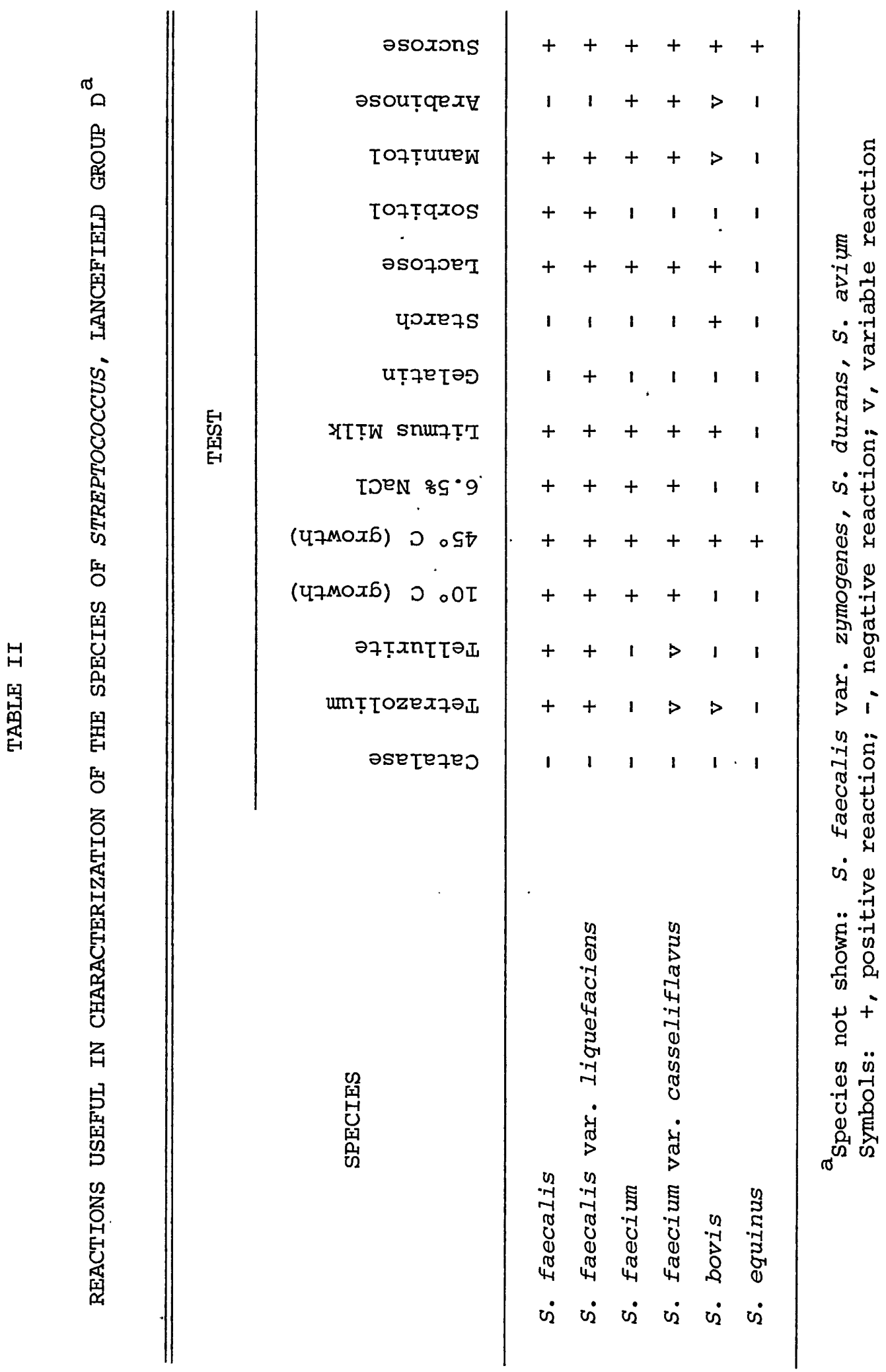


REACTIONS OF IDENTIFIED SPECIES OF STREPTOCOCCUS, LANCEFIELD GROUP Da

SPECIES
S. faecalis
S. faecium
S. faecium var.

TEST casseliflavus

NUMBER OF ISOLATES

8

8

5

\begin{tabular}{lccc}
\hline Catalase & $100(-)$ & $100(-)$ & $100(-)$ \\
Tetrazolium & $100(+)$ & $100(-)$ & $80(+)$ \\
Tellurite & $100(+)$ & $100(-)$ & $80(+)$ \\
10 C (growth) & $100(+)$ & $100(+)$ & $100(+)$ \\
$45^{\circ}$ C (growth) & $100(+)$ & $100(+)$ & $100(+)$ \\
$6.5 \%$ NaCl & $100(+)$ & $100(+)$ & $100(+)$ \\
Litmus Milk & $100(+)$ & $100(+)$ & $100(+)$ \\
Gelatin & $100(-)$ & $100(-)$ & $100(-)$ \\
Starch & $100(-)$ & $100(-)$ & $100(-)$ \\
Lactose & $100(+)$ & $100(+)$ & $100(+)$ \\
Sorbitol & $100(+)$ & $100(-)$ & $100(-)$ \\
Mannitol & $100(+)$ & $100(+)$ & $100(+)$ \\
Arabinose & $88(+)$ & $88(+)$ & $100(+)$ \\
Sucrose & $100(+)$ & $(+)$ & $100(+)$ \\
\hline
\end{tabular}

aumbers indicate percentage of species exhibiting the reaction shown in parenthesis. 
isolates of group id streptococci found in the burn unit.

Table IV shows the antibiotic susceptibility tests results of the three species of Streptococcus, Lancefield Group D. As a whole, all of the strains of group D streptococci were resistant to most of the antibiotics tested. The strains of $S$. faecalis were uniformly more resistant to the antibiotics tested than were the other two species of Streptococcus. The extreme resistance to antibiotics of S. faecalis is well documented. $(22,23,25)$. The strains of $S$. faecium were more resistant, as a group, than were the strains of S. faecium var. casseliflavus. The strains of $S$. faecium were 100 percent resistant to ten antibiotics, whereas the strains of $S$. faecium var. Casseliflavus. were 100 percent resistant to six antibiotics.

An attempt. was made to correlate a particular antibiotic susceptibility pattern, to each of the three species of streptococcus. No definite patterns were found that were broad-based enough to use as a species differentiation criteria. The only antibiotic tested that yielded a clearly species-specific difference was novobiocin. The strains of S. faecalis were 100 percent resistant to novobiocin, whereas the strains of both $S$. faecium and $S$. faecium var. casseliflavus were 100 percent sensitive. The only strains showing sensitivity to cefamandole, penicillin and cephalothin were the five isolates of $S$. faecium var. casseliflavus. All eight isolates of S. faecium were resistant to nitrofurantoin, in contrast to the high sensitivity shown by the isolates of $S$. faecalis ( 88 percent susceptible) and the isolates of $S$. faecium var. casseliflavus (100 
TABLE IV

ANTIBIOTIC SUSCEPTIBILITY OF ISOLATES OF GROUP D STREPTOCOCCUS ${ }^{\text {a }}$ SPECIES
S. Faecalis
S. faecium
S. faecium

var.

ANTIBIOTIC casseliflavus

NUMBER OF ISOIATES

$\cdot 8$

8

5

\begin{tabular}{|c|c|c|c|}
\hline Cefmandole & 0 & 0 & 60 \\
\hline Tobramycin & 0 & 0 & 0 \\
\hline Garbenicillin & 12 & 0 & 80 \\
\hline Penicillin & 0 & 0 & 80 \\
\hline Cephalothin & 0 & 0 & 80 \\
\hline Tetracycline & 12 & 75 & 80 \\
\hline Methicillin & 0 & 0 & 0 \\
\hline Chloramphenicol & 25 & 100 & 60 \\
\hline Cefoxitin & 0 & 12 & 0 \\
\hline Novobiocin & 0 & 100 & 100 \\
\hline Nitrofurantoin & 88 & 0 & 100 \\
\hline Gentamicin & 0 & 0 & 0 \\
\hline Erythromycin & 50 & 0 & 60 \\
\hline Amikacin & 0 & 0 & 0 \\
\hline Clindamycin & 0 & 12 & 0 \\
\hline
\end{tabular}

Numbers represent percentage of each species susceptible to the listed antibiotics. 
percent susceptible). Taken as an entire group, tetracycline resistance was found in 48 percent of the twenty-one group D streptococci, erythromycin resistance was found in 66 percent and chloramphenicol resistance noted in 38 percent of the total isolates. In contrast, a 1977 study of clinical. isolates of group D streptococci found that 58 percent were resistant to tetracycline, 12 percent were resistant to erythromycin and 14 percent were resistant to chloramphenicol (26). Resistance to these three antibiotics is known to be plasmid-mediated $(25,26)$, as is resistance to the animoglycoside antibiotics such as tobramycin and gentamicin $(47,48)$. All isolates of the group D streptococci found in this investigation were 100 percent resistant to both tobramycin and gentamicin.

The MIC of silver nitrate for the three identified species of Streptococcus are shown in Table V. Nothing remarkable was found in the analysis of this data with respect to increasing resistance to silver from the selective pressure of Silvadene®. The effectiveness of silver as an antimicrobial agent is well known (44). It was assumed that as therapy with Silvadene ${ }^{\circledR}$ continued, a pattern of increasing resistance to silver would emerge. The data, however, did not support this assumption. The single strain of $S$. faecalis sensitive to a concentration of silver ion between $0.79 \mu \mathrm{g} / \mathrm{ml}$ and $1.58 \mu \mathrm{g} / \mathrm{ml}$ was eradicated early, and was not followed by any other isolate of the Streptococcus." The two sensitive S. faecium var. casseliflavus were also eradicated early. in the course of therapy, and were not succeeded by any other $s$. faecium var. casseliflavus that were more resistant. As a whole, 86 percent of the isolates 
TABIE V

MINIMUM INHIBITORY CONCENTRATIONS OF SILVER NITRATE (SPECIES OF GROUP D STREPTOCOCCUS)

CONCENTRATION AgNO 3 ( $\mu \mathrm{g} / \mathrm{mI})$

SPECIES

$\begin{array}{llll}10^{\mathrm{b}} & 5^{\mathrm{c}} & 2.5^{\mathrm{d}} & 1.25^{\mathrm{e}}\end{array}$

S. feacalis

0

88

12

0

S. faecium

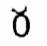

100

0

0

S. faecium var.

0

60

40

0

casseliflavus

Numbers represent percentage of each species exhibiting MIC at the listed concentrations.

Corresponds to $6.35 \mu \mathrm{g} / \mathrm{ml}$ silver ion.

Corresponds to $3.17 \mu \mathrm{g} / \mathrm{ml}$ silver ion.

Corresponds to $1.58 \mu \mathrm{g} / \mathrm{ml}$ silver ion.

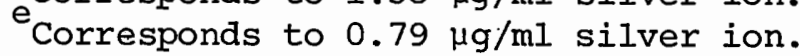


of group D streptococci were inhibited by concentrations of silver ion between $1.58 \mu \mathrm{g} / \mathrm{ml}$ and $3.17 \mu \mathrm{g} / \mathrm{ml}$. No strains of $S$. faecium were inhibited by concentrations of silver ion less than $1.58 \mu \mathrm{g} / \mathrm{ml}$. The relatively high resistance to silver ion is of little consequence, in that SiIvadene® ointment releases much higher quantities of silver ion than the bacteria are resistant to, e.g., up to $4.31 \times 10^{4} \mu \mathrm{g} / \mathrm{ml}$ ointment.

INDIVIDUAI ANALYSIS OF THE ISOLATES OF GROUP D STREPTOCOCCUS

\section{Streptococcus faecalis}

The eight strains of $S$. faecalis yielded five distinct biochemical phenotypes and seven different antimicrobial susceptibility patterns. There were two strains exactly alike. Both were isolated from a single patient and were only present for a two week period.

\section{Streptococcus faecium}

The eight strains of $\dot{s}$. faecium yielded two distinct biochemical phenotypes and six different antimicrobial susceptibility patterns. There were three strains exactly alike. All three "like" strains were isolated from a single patient and were only present for a one week period.

Streptococcus faecium var. casseliflavus

The five strains of $S$. faecium var. casseliflavus yielded four distinct biochemical phenotypes and five different antimicrobial susceptibility patterns. There were no isolates exactly alike in this group. 
From the above data it does not appear that a particular streptococcal bacterium can be implicated as a resident in the OBC. AIthough the species of streptococcus were resistant to a wide variety of antibiotics, as well as moderate concentrations of silver, the isolates of the group D streptococci were easily. eliminated from each and every patient who became colonized with them, and within two weeks of their detection.

\section{SPECIES OF STAPHYLOCOCCUS}

Using the criteria shown in Table VI, isolates of Staphylococcus were differentiated into seven biochemically distinct species, namely: S. aureus, s. cohnii, s. epidermidis, S. haemolyticus, s. hominis, S. simulans and $S$. warneri. Table VII. shows the reactions of the forty-five species of Staphylococci on a cumulative percentage basis. In the $O B C$ these isolates were found in the following percentage distribution: S. aureus, 29 percent (twenty-two strains) and $S$. epidermidis, 29 percent (thirteen isolates). The remaining 22 percent (ten isolates) were coagulase-negative strains of Staphylococcus other than S. epidermidis, and were isolated from six patients only (33 percent of the sample).

The species of $S$. aureus were easily differentiated from other species of Staphylococcus by their ability to produce coagulase, their sensitivity to lysostaphin and phosphatase production. Species that satisfied the above criteria were further subjected to a limited number of confirmatory. biochemical tests. Species differentiation among the coagulase-negative strains of Staphylococcus was much more 


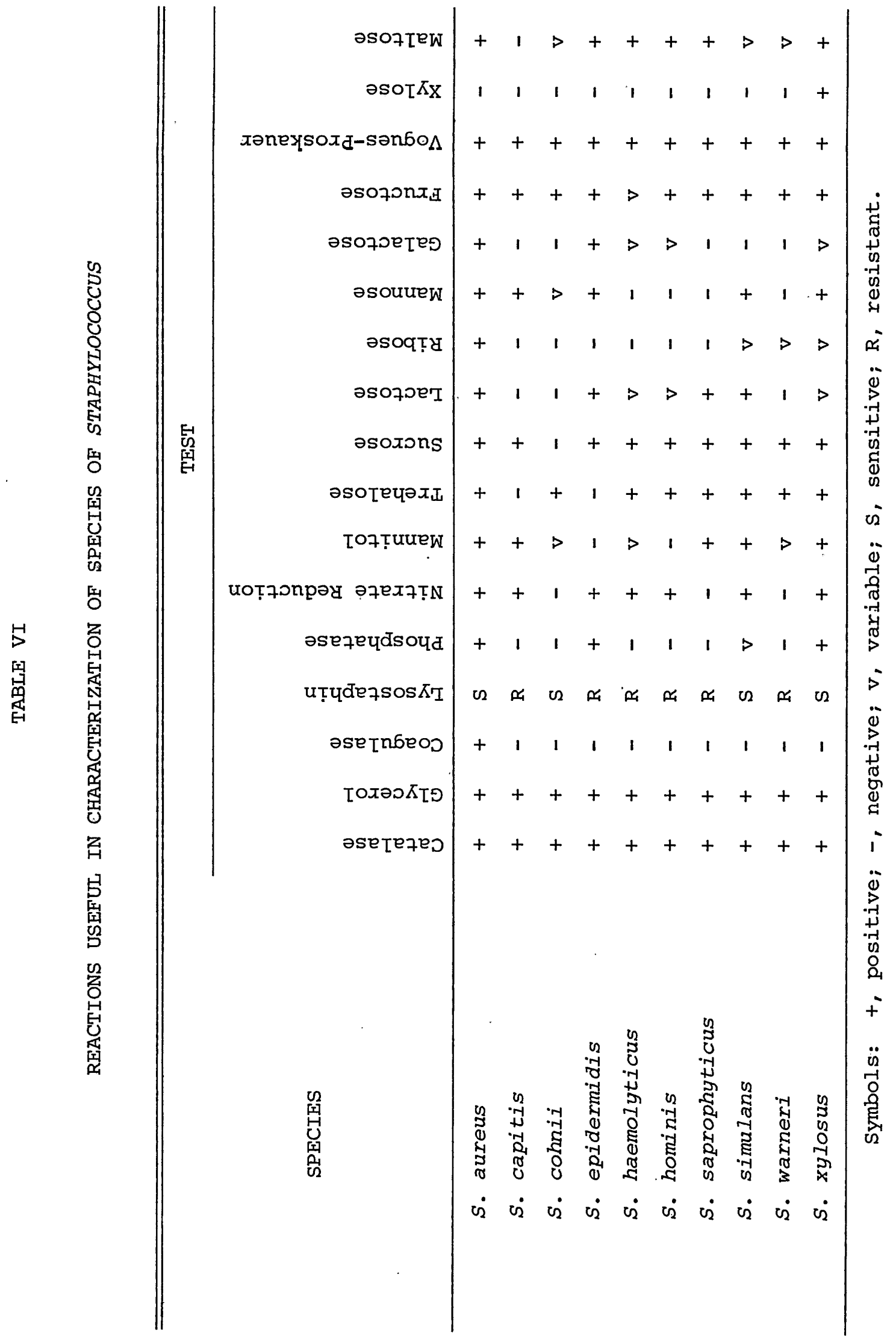




\section{TABLE VII}

REACTIONS OF IDENTIFIED SPECIES OF STAPHYLOCOCCUS ${ }^{\mathrm{a}}$

\begin{tabular}{|c|c|c|c|c|c|c|c|}
\hline \multirow{3}{*}{ TEST } & \multicolumn{7}{|c|}{ SPECIES } \\
\hline & 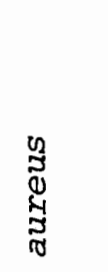 & 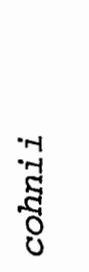 & 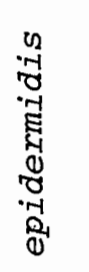 & 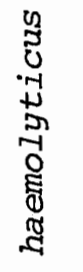 & 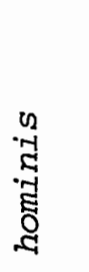 & 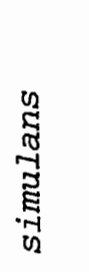 & 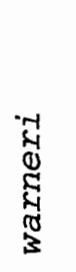 \\
\hline & $\dot{v}$ & $\dot{\varphi}$ & $\dot{\varphi}$ & $\dot{\underline{r}}$ & $\dot{2}$ & $\dot{v}$ & $\dot{2}$ \\
\hline Catalase & 100 & 100 & 100 & 100 & 100 & 100 & 100 \\
\hline Glycerol & 100 & 100 & 100 & 100 & 100 & 100 & 100 \\
\hline Coagulase & 100 & 100 & 100 & 100 & 100 & 100 & 100 \\
\hline Lysostaphin & 82 & 100 & 100 & 100 & 100 & 100 & 100 \\
\hline Phosphatase & 100 & 100 & 93 & 100 & 100 & 100 & 100 \\
\hline Nitrate Reduction & $n t^{b}$ & $100^{\circ}$ & 92 & 100 & 100 & 100 & 50 \\
\hline Mannitol & 86 & 100 & 80 & 0 & 100 & 0 & 0 \\
\hline Trehalose & 95 & 100 & 100 & 100 & 100 & 100 & 100 \\
\hline Sucrose & nt & 100 & 93 & 100 & 100 & 100. & 100 \\
\hline Iactose & nt & 100 & 100 & 0 & 100 & 100 & 100 \\
\hline Ribose & 100 & 100 & 93 & 0 & 100 & 0 & 100 \\
\hline Mannose & nt & 100 & 60 & 100 & 100 & 100 & 100 \\
\hline Galactose & 91 & 50 & 100 & 100 & 100 & 0 & 100 \\
\hline Fructose & nt & 100 & 100 & 0 & 100 & 100 & 100 \\
\hline Vogues-Proskauer & nt & 0 & 93 & 0 & 67 & 0 & 50 \\
\hline Xylose & 100 & 100 & 100 & 100 & 100 & 100 & 100 \\
\hline Maltose & nt & 100 & 100 & 100 & 100 & 100 & 100 \\
\hline
\end{tabular}

Numbers represent percentage of each species exhibiting reaction shown in Table VI; where reaction is variable, numbers represent percentage of species exhibiting a bositive reaction. nt: Not Tested. 
extensive, as some species are differentiated only among a limited number of carbohydrate fermentation abilities. No strains of $S$. capitis, S. saprophyticus or $S . x y l o s u s$ were identified. The series of biochemical tests employed to differentiate the coagulasenegative species of staphylococcus was adequate.

Table VIII shows the antibiotic susceptibility test results of the seven identified species of Staphylococcus. The strains of $S$. aureus, as a whole, were relatively susceptible to the ten antibiotics tested, although they were 100 percent resistant to both cefamandole and penicillin. of the coagulase-negative species of Staphylococcus, s. cohnii was the most sensitive strain isolated, being resistant to only methicillin. The strains of $S$. hominis exhibited the greatest resistance to the antibiotics tested, being 100 percent susceptible to only novobiocin and clindamycin. The S. epidermidis were the strains more uniformly resistant to a.ll antibiotics tested than were the other coagulase-negative species, except $S$. hominis as noted above. The relative resistance of the coagulasenegative Staphylococcus strains to antibiotics has been previously noted $(33,37)$.

Methicillin-resistant strains of staphylococcus are considered of importance in the hospital setting and methicillinresistant $S$. epidermidis are becoming common $(32,33)$. Methicillin ręsistance was observed in only one of the twenty-two strains of $S$. aureus, whereas resistance was observed in eight of the thirteen strains of $s$. epidermidis. The $S$. cohnii, $S$. hominis and $S$. simulans strains were 100 percent resistant to methicillin. 
TABLE VIII

ANTIBIOTIC SUSCEPTIBILITY OF SPECIES OF- STAPHYLOCOCCUS ${ }^{a}$

\begin{tabular}{|c|c|c|c|c|c|c|c|}
\hline \multirow{3}{*}{ ANTIBIOTIC } & \multicolumn{7}{|c|}{ SPECIES } \\
\hline & 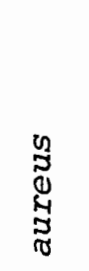 & $\begin{array}{l}-1 \\
-1 \\
\mathbb{A} \\
0 \\
0\end{array}$ & 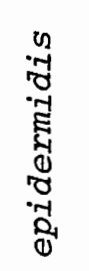 & 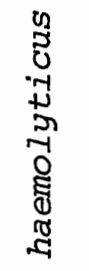 & 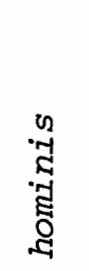 & 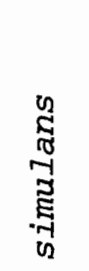 & 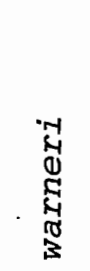 \\
\hline & $\dot{2}$ & $\dot{\varphi}$ & $\dot{2}$ & $\dot{v}$ & $\dot{2}$ & $\dot{\varphi}$ & $\dot{\varphi}$ \\
\hline Cefmandole & 0 & 100 & 23 & 0 & 0 & 0 & 50 \\
\hline Penicillin & 0 & 100 & 15 & 0 & 0 & 0 & 50 \\
\hline Cephalothin & 100 & 100 & 100 & 100 & 0 & 100 & 100 \\
\hline Tetracycline & 86 & 100 & 85 & 0 & 33 & 100 & 100 \\
\hline Methicillin & 91 & 0 & 38 & 100 & 0 & 0 & 100 \\
\hline Chloramphenicol & 95 & 100 & 100 & 100 & 0 & 100 & 100 \\
\hline Cefoxitin & 95 & 100 & 54 & 100 & 0 & 100 & 100 \\
\hline Novobiocin & 95 & 100 & 100 & 100 & 100 & 100 & 100 \\
\hline Erythromycin & 100 & 100 & 77 & 100 & 0 & 100 & 100 \\
\hline Clindamycin & 95 & 100 & 85 & 100 & 100 & 100 & 100 \\
\hline
\end{tabular}

a Numbers represent percentage of each species susceptible to the listed antibiotic. 
Susceptibility by species to the inorganic salts of arsenate $\left(\mathrm{Na}_{2} \mathrm{AsO}_{4}\right)$, arsenite $\left(\mathrm{NaAsO}_{2}\right)$ and mercury $\left(\mathrm{HgCl}_{2}\right)$ are shown in Table IX. The discs used in the test were impregnated with the following concentrations of ion: arsenate, $1.49 \times 10^{2} \mu \mathrm{g}$; arsenite, $1.48 \times 10^{3} \mu \mathrm{g}$; and mercury, $4.00 \mu \mathrm{g}$. Only 7 percent of the total strains of Staphylococci were resistant to arsenate while 64 percent of the total strains of Staphylococci were resistant to arsenite. Resistance to mercury was observed in 38 percent of all strains of Staphylococci. The strains of $S$. aureus were much more susceptible to arsenite (55 percent) than were the coagulase-negative species (17 percent). Resistance. to these inorganic antimicrobial agents has been plasmid-linked, at least in S. aureus (39). Resistance to mercury may be due to the action of a mercuric reductase which volatilizes mercury $(49,50)$.

Table $\mathrm{X}$ details the MIC data of silver for the species Staphylococcus. Ninety-five percent of the $S$, aureus isolates. were inhibited by a silver ion concentration between $1.58 \mu \mathrm{g} / \mathrm{ml}$ and $3.17 \mu \mathrm{g} / \mathrm{ml}$, as were the two strains of $S$. cohnii. The strains of S. epidermidis showed the greatest variability in their sensitivity to silver ion. The majority of the strains (62 percent) exhibited sensitivities between $0.79 \mu \mathrm{g} / \mathrm{ml}$ and $1.58 \mu \mathrm{g} / \mathrm{ml}$ silver ion. The isolates of $\mathrm{S}$. epidermidis were the only strains of staphylococcus (or streptococcus) that exhibited susceptibility to silver ion at a concentration between $0.4 \mu \mathrm{g} / \mathrm{ml}$ and $0.79 \mu \mathrm{g} / \mathrm{ml}$. As would be expected, these sensitive strains were quickly eliminated from each of the two patients harboring them. 
SUSCEPTIBILITY OF SPECIES OF STAPHYLOCOCCUS TO INORGANIC

SAITS OF ARSENATE, ARSENITE AND MERCURY ${ }^{a}$

INORGANIC SALT

SPECIES

$\begin{array}{ccc}\operatorname{Arsenate}^{\mathrm{b}} & \begin{array}{c}\text { Arsenite } \\ \left(\mathrm{Na}_{2} \mathrm{AsO}_{4}\right)\end{array} & \begin{array}{c}\text { Mercury }^{\mathrm{C}} \\ \left(\mathrm{NaASO}_{2}\right)\end{array}\end{array}$

S. aureus

$21 / 22$

$12 / 22$

$17 / 22$

S. cohnii

$2 / 2$

$0 / 2$

$1 / 2$

S. epidermidis

$13 / 13$

$0 / 13$

$4 / 13$

s. haemolyticus

$1 / 1$

$1 / 1$

$1 / 1$

s. hominis

$1 / 3$

$0 / 3$

$1 / 3$

S. simulans

$2 / 2$

$1 / 2$

$2 / 2$

S. warneri

$2 / 2$

$2 / 2$

$2 / 2$

a Numbers indicate: susceptible species/number species tested. Disc impregnated with $0.02 \mathrm{ml}$ of a $0.1 \mathrm{M}$ solution. CDisc impregnated with $0.02 \mathrm{ml}$ of a $1.0 \mathrm{M}$ solution. Disc impregnated with $0.02 \mathrm{ml}$ of a $10^{-3} \mathrm{M}$ solution. 
TABLE X

MINIMUM INHIBITORY CONCENTRATIONS OF SILVER NITRATE (SPECIES OF STAPHYLOCOCCUS)

\begin{tabular}{|c|c|c|c|c|}
\hline \multirow{2}{*}{ SPECIES } & \multicolumn{4}{|c|}{ CONCENTRATION $\mathrm{AgNO}_{3}(\mu \mathrm{g} / \mathrm{ml})$} \\
\hline & $10^{b}$ & $5^{c}$ & $2.5^{\mathrm{d}}$ & $1.25^{e}$ \\
\hline S. aureus & 0 & 95 & 5 & 0 \\
\hline S.. cohnii & 0 & 100 & 0 & 0 \\
\hline S. epidermidis & 0 & 23 & 62 & 15 \\
\hline S. haemolyticus & 0 & 100 & 0 & 0 \\
\hline S. hominis & 0 & 33 & 67 & 0 \\
\hline S. simulans. & 0 & 0 & 100 & 0 \\
\hline S. warneri & 0 & 50 & 50 & 0 \\
\hline
\end{tabular}

Numbers represent percentage of each species exhibiting MIC at the listed concentrations.

Corresponds to $6.35 \mu \mathrm{g} / \mathrm{ml}$ silver ion.

Corresponds to $3.17 \mu \mathrm{g} / \mathrm{ml}$ silver ion.

Corresponds to $1.58 \mu \mathrm{g} / \mathrm{ml}$ silver ion.

eorresponds to $0.7 .9 \mu \mathrm{g} / \mathrm{ml}$ silver ion. 
INDIVIDUAL ANALYSIS OF THE ISOLATES OF STAPHYLOCOCCUS

\section{Staphylococcus aureus}

The twenty-two strains of $s$. aureus yielded seven distinct biochemical phenotypes and fourteen different antibiotic and antimicrobial agent susceptibility patterns. Three of the strains from a single patient were exactly alike, and presumed to be clones. The two strains of $S$. aureus from two different patients were exactly alike, but were eliminated from both patients within one week of their detection. The strains of $S$. aureus were the most homogeneous group in the investigation with respect to biochemical phenotypes.

\section{Staphylococcus cohnii}

The two strains of $S$. Cohnii were different in both biochemical phenotype and antibiotic and antimicrobial agent susceptibility patterns. They were isolated from a single patient, and were presumed to be indigenous skin flora.

\section{Staphylococcus epidermidis}

The thirteen strains of $S$. epidermidis yielded eight distinct biochemical phenotypes and ten different antibiotic and antimicrobial agent susceptibility patterns. There were no two isolates exactly alike in this group of staphylococci.

\section{Staphy lococcus haemolyticus}

The single strain of $S$. haemolyticus was isolated from one patient and was present in the first culture only. It was presumed to be indigenous skin flora. 
Staphylococcus hominis

The three strains of $S$. hominis yielded three distinct biochemical phenotypes and two different antibiotic and antimicrobial agent susceptibility patterns. There were no isolates exactly alike in this group.

\section{Staphylococcus simulans}

The two strains of $S$. simulans found were biochemically alike and had the same antibiotic and antimicrobial agent susceptibility patterns. They were isolated from a single patient, assumed to be clones, and presumed to be indigenous skin flora.

\section{Staphylococcus warneri}

The two strains of $S$. warneri yielded two distinct biochemical phenotypes and two different antibiotic and antimicrobial agent susceptibility patterns. Thus, these two strains were not alike.

From the above data, the strains of $S$. aureus were the isolates which were most similar in phenotype. The S. aureus, however, are also the species of Staphylococcus most. easily identified by the least number of biochemical tests, so possible permutations of phenotypes were limited. Among the isolates of staphylococcus, no apparent resident bacterium could be identified. The variety of staphylococcus spp. and the range of biochemical phenotypes precluded finding enough "like" isolates to qualify as a nosocomial bacterium.

\section{SILVER SUSCEPTIBIIITY, AGAR-DIIUTION}


were determined in $\mathrm{AgNO}_{3}-\mathrm{MHB}$. Susceptibility to silver was also performed in tryptone-glucose agar. This media was initially chosen because of its relative lack of chloride, which combines with silver ion to form the insoluble silver chloride. This series of tests yielded no results. All strains of staphylococcus and streptococcus grew on all plates, including the plate containing the highest concentration of silver ion $(9.56 \mu \mathrm{g} / \mathrm{ml})$. In view of the data collected previously for the tube dilution method, the results were not acceptable. For those strains inhibited by $3.17 \mu \mathrm{g} / \mathrm{ml}$ silver ion, the agar contained more than three times the inhibitory concentration of silver ion than in the $\mathrm{AgNO}_{3}-\mathrm{MHB}$. For the isolates inhibited by $1.58 \mathrm{\mu g} / \mathrm{ml}$ silver ion in the tube-dilution test, the agar contained more than six times the inhibitory concentration of silver ion. A possible explanation for this discrepancy may be that the silver ion combined with the free sulfate groups in the agar, leading to the formation of an insoluble compound, silver sulfate. In this bound form the silver would have been unavailable to interact with, and thus inhibit, the growth of the bacterial species.

\section{BACTERIAI SUCCESSION}

The change (succession) in burn flora over time was analyzed. Table XI shows the variety of organisms isolated in the first positive bacterial culture of each patient. The fact that several patients exhibited mixed cultures initially made succession study difficult. Species of Staphylococcus were isolated first from 89 percent of the burn victims entering the OBC. 
TABLE $\cdot X I$

BACTERIA ISOLATED FROM PATIENTS AS A FIRST CULTURE

S. aureus only

S. epidermidis only

Other species of Staphylococcus:

s. warneri only 1

S. haemolyticus only 1

S. hominis only 1

Group D Streptococcus:

S. faecalis only' 1

S. faecalis + S. faecium var. casseliflavus 1

S. epidermidis + S. simulans 1

S. aureus + S. epidermidis + S. warneri . 1

S. epidermidis + Group D S. faecium var. casseliflavus 1

andicates number of patients whose first culture after entering the burn unit yielded the stated organism(s). 
In the average length of stay (nineteen days), eight patients harbored a series of different species of bacteria, i.e., they were colonized at some time by any combination of species of streptococcus, a strain. of $S$. aureus and/or a $S$. epidermidis or other coagulasenegative species of Staphylococcus. (See Table XII for an example of a typical patient's diverse bacterial flora through time.) of these eight patients, two were not ever colonized with any of the species of Streptococcus, one patient had only different coagulase-negative species of Staphylococcus, and one patient had only different strains of S. aureus. The four patients with notable series of bacterial succession had a $S$. aureus as the final organism isolated before leaving the burn unit. Of these patients, one began with a strain of $S$. aureus, one began with a mixed culture of both a $S$. epidermidis and S. faecium var. casseliflavus, one patient began with $S$. haemolyticus, and one began with two different strains of $S$. hominis. All four of these patients had positive cultures of streptococcus during their course of stay at the OBC, but these. species were always eliminated before the final colonization with $S$. aureus. The limited number of patients showing successive colonization facilitated analysis of the data. No pattern of colonization was evident which was totally consistant between all four patients, other than the fact that $S$. aureus was the most persistent organism of all the species. Iittle is known about burn wound ecology which would aid in determining whether the factors involved that favor $S$. aureus colonization in late healing are intrinsic to the wound, or are favored by other, extrinsic factors. 
TABLE XII

SEQUENTIAL ISOLATION OF BACTERIA

(ONE PATIENT)

DATE OF

ISOLATION

ORGANISM (S)

$11 / 11 / 80$

Staphylococcus aureus

$11 / 18 / 80$

streptococcus faecium

$11 / 19 / 80$

Streptococcus faecium*

Streptococcus faecium var. casseliflavus

$11 / 21 / 80$

Streptococcus faecium*

$11 / 24 / 80$

Staphylococcus epidermidis

$(2)^{a}$

streptococcus faecalis

Streptococcus faecium*

streptococcus faecium

$12 / 18 / 80$

Staphylococcus aureus

*

Indicates species which gave same reaction pattern for all tests. All other isolates were intraspecifically different.

andicates two different strains isolated. 


\section{LIMITATIONS OF THE INVESTIGATION}

The scope of the investigation was limited in that access to the patients was available only to burn unit personnel. Since there was no control over any aspect concerning the patients and their bacteria previous to receiving the isolates, the investigation had many unknown and uncontrollable variables. For example, when sub-eschar clysis was performed, and isolates received, there was no way of ascertaining whether the bacteria cultured were from inside the wound itself, or on the skin (leading edge of the wound). Ideally, a sampling of the skin flora on unburned skin, and nasal passages, of the patients should have been done to determine which species of bacteria (particularly the species of Staphylococcus) were truly indigenous. 
CHAPTER IV

SUGGESTIONS FOR FURTHER RESEARCH

Gram-positive bacterial species were investigated because the current literature pertains, for the most part, to the problems associated with the gram-negative species in burn wound infections. Also, a study of this nature had not been previously undertaken. It was apparent throughout the course of this investigation that certain refinements might have been desirable. Monitering the isolates for a longer time period (e.g., six months to one year) might have aided in detection of both a nosocomial bacterium and in finding stable patterns of bacterial succession. Including gram-negative strains also found in burn wounds (e.g., Pseudomonas aeruginosa) would also have been of value for succession studies. The $S$. aureus strains, in the future, should be subjected to more extensive tests for phenotyping. In cases where particular bacteria were implicated (or suspected) of being nosocomially transmitted, phage typing of the bacteria would be of value. Agarose gel electrophoresis of plasmid DNA would also be invaluable in fingerprinting the isolates for similarity. 


\section{CHAPTER V}

\section{SUMMARY}

Species of streptococcus and staphylococcus from hospitalized patients at the OBC were monitored. All bacterial strains were characterized by biochemical tests and susceptibility to various antimicrobial agents, including antibiotics.

There was no evidence of increasing resistance to silver due to selective pressure from the use of Silvadene ${ }^{\circledR}$ ointment. There was no evidence of a nosocomial bacterium present in the OBC according to the data collected. Bacterial succession studies yielded no distinctiṿe pattern among the patients. It appeared as if patients entered and left the burn unit with their indigenous flora.

The data presented in this investigation also showed that while multiple antibiotic-resistant bacteria do colonize burn victims, appropriate and timely antimicrobial therapy can spare the patient of bacteremia. 


\section{BIBLIOGRAPHY}

1. Monafo, W. W. and C. A. Moyer. 1968. The Treatment of Extensive Thermal Burns with 0.5\% Silver Nitrate Solution. Ann. NY Acad. Sci. $150(3): 937-945$.

2. Cotran, R. S. and J. P. Remensnyder. 1968. The Structural Basis of Increased Vascular Permeability after Graded Thermal Injury - Light and Electron Microscopic Studies. Ann. NY Acad. Sci. $150(3): 495-509$.

3. Heggers, J. P. et. al. 1980. Evaluation of Burn Blister Fluid. Plast. Reconstr. Surg. $65(6): 798-804$.

4. Enson, Y. et. al. 1968. Hemodynamic Effects of Metabolic Acidosis in Cholera: Implications for Fluid Repletion in severe Burns. Ann. NY Acad. Sci. $150(3): 577-583$.

5. Zimmermann, W. E. 1968. Acidosis in Severe Burns. Ann. NY Acad. Sci. $150(3): 584-603$.

6. Guest, M. M. and T. P. Bond. 1968. Release of Thromboplastin after Thermal Injury. Ann. NY Acad. Sci. 150 (3):528-536.

7. Rozin, R. et. al. 1968. Studies on Insensible Water Loss from Burns Treated Para-Aminomethyl Benzene Sulfonamide (Sulfamylon): Ann. NY Acad. Sci. $150(3): 778-787$.

8. Goodwin, C. W. et. al. 1980. Increased Renal Perfusion and Kidney Size in Convalescent Burn Patients. JAMA 244(14):15881590.

9. Goodall, M. 1968. Sympatho-Adrenal Medullary Response to Thermal Burn. Ann. NY Acad. Sci. $150(3): 685-689$.

10. Vistnes, I. M. and G. R. Hogg. 1971. The Burn Eschar. Plast. Reconstr. Surg. 48 (1) 50-60.

11. Luterman, A. and P. W. Curreri. 1980. Bac-Data Perspective on Infection: A Computer-aided Analysis of Clinical Infection. Medical Information Systems, Inc. Clifton, N. J. 3(1):1-4.

12. Knisley, M. H. 1968. Enforced Postponement of Selective Phagocytosis Following Burns: A Contribution to the Biophysics of Disease. Ann. NY Acad. Sci. $150(3): 510-527$. 
13. Markley, K. 1968. The Role of Bacteria in Burn Mortality. Ann. NY Acad. Sci. $150(3): 922-930$.

14. Lindberg, R. B., J. A. Moncrief and A. D. Mason, Jr. 1968. Control of Experimentai and Clinical Burn Wound Sepsis by Topical Application of Sulfamylon Compounds. Ann. NY Acad. Sci. $150(3): 950-960$.

15. Baxter, C. R., P. W. Curreri, and J. A. Marvin. 1973. The Control of Burn Wound Sepsis by the Use of Quantitative Bacteriologic Studies and Subeschar Clysis with Antibiotics. Surg. Clin. N. Am. $53(6): 1509-1517$.

16. Burke, J. F., C. C. Bondoc and P. J. Morris. 1968. Metabolic Effects of Topical Silver Nitrate Therapy in Burns Covering more than Fifteen Percent of the Body Surface. Ann. NY Acad. Sci. $150(3): 674-681$.

17. Edlich, R. F. et. al. 1977. Practical Bacteriologic Monitoring of the Burn Victim. Changes. Plast. Surg. 4(1):561-569.

18. Facklam, R. D. 1972. Recognition of Group D streptococcal Species of Human Origin by Biochemical and Physiologic Tests. App1. Microbiol. $23(6)$ :1131-1139.

19. Hartman, P. A., G. W. Reinbold and S. S. Saraswat. 1966. Indicator Organisms - A Review. I Taxonomy of the Fecal streptococci. Int. J. Syst. Bacteriol. 16(2):197-221.

20. Jones, D. 1978. Composition and Differentiation of the Genus Streptococcus. In: Streptococci (The Society for Applied Bacteriology Symposium Series No. 7), Eds. Skinner, F. A. and I. B. Quesnel; Academic Press. pp. 1-49.

21. MacFaddin, J.F. n.d. Biochemical Tests for Identification of Medical Bacteria, 2nd ed. (n.p.:n.p.). p. 347 •

21a. - p. 346

21b. -

21c. - -

21d. - 236-245

$21 \mathrm{e} \cdot-308-320$

22. Fuchs, P. C. n.d. Identification and Antibiotic Susceptibility Testing of Group D Streptococci. In: R. N. Jones (ed.), TIS (Microbiology). 19:44-67. 
23. Parker, M. T. 1978. The Pattern of Streptococcal Disease in Man. pp. 71-102. In: Streptococci (The Society for Applied Bacteriology Symposium Series No. 7), Eds. Skinner, F. A. and L. B. Quesnel. Academic Press.

24. Mossel, D. A. A., Bijker, P. G. H. and I. Eelderink. 1978. Streptococci of Lancefield Group A, B and D and Those of Buccal Origin in Foods: Their Public Health Significance, Monitoring and Control. pp. 315-329. In: Streptococci (The Society for Applied Bacteriology symposium Series No. 7), Eds. Skinner, F. A. and L. B. Quesne1. Academic Press.

25. Kono, M., H. Hamashima and M. Sasatsu. 1980. Properties of the Transferable Antibiotic-resistance Determinants of Streptococcus faecalis. Microbios Lett. 13:149-155.

26. Van Embden, J. D. A., H. W. B. Engel and B. Van Klingeren. 1977. Drug Resistance in Group D Streptococci of Clinical and Nonclinical origin: Prevalence, Transferability, and Plasmid Properties. Antimicrob. Agents Chemother. 11(6):925-932.

27. Schleifer, K. H. and W. E. Kloos. 1975. Isolation and Characterization of Staphylococci from Human Skin. I. Amended Descriptions of Staphylococcus epidermidis and Staphylococcus saprophyticus and Descriptions of Three New Species: Staphylococcus cohnii, staphylococcus haemolyticus, and staphylococcus xylosus. Int. J. Syst. Bacteriol. $25(1): 50-61$.

28. Kloos, W. E. and K. H. Schleifer. 1975. Simplified Scheme for Routine Identification of Human Staphylococcus Species. J. Clin. Microbiol. $1(1): 82-88$.

29. Buchanan, R. E. and N. E. Gibbons (eds.) 197.4. Bergey's Manual of Determinative Bacteriology. 8th Ed. Williams \& Wilkins Co. Baltimore, MD. pp. 483-509.

30. Mabeck, C. E. 1969. Significance of Coagulase-Negative Staphylococcal Bacteriuria. Lancet ii(7631):1150-1152.

31. Quinn, E. L. and F. Cox. 1965. The Problem of Associating Coagulase-Negative Staphylococci with Disease. Ann. NY Acad. Sci. $128(1): 428-442$.

32. Ivler, D. 1965. Comparative Metabolism of Virulent and Avirulent Staphylococci. Ann. NY Acad. Sci. $128(1): 62-80$.

33. Marski, F. J. and J. T. Parisi. 1973. Significance of Staphylococcus epidermidis in the Clinical Laboratory. AppI. Microbio1.. 25(1):11-14. 
34. Barnes, E. M. 1956. Tetrazolium Reduction as a Means of Differentiating Streptococcus faecalis from Streptococcus faecium. J. Clin. Microbiol. 1(3):337-338.

35. Schleifer, K. H. and W. E. Kloos: 1975. A Simple Test System for the Separation of Staphylococci from Micrococci. J. Clin. Microbiol. 1(3):337-338.

36. Severance, P. J., C. A. Kauffman and J. N. Sheagren. 1980. Rapid Identification of Staphylococcus aureus by Using Lysostaphin Sensitivity. J. Clin. Microbiol. 11(6):724-727.

37. Wilkinson, B. J., S. Maxwell and S. M. Schaus. 1980. Classification and Characteristics of Coagulase-Negative, MethicillinResistant Staphylococci. J. Clin. Microbiol. 12(2):161-166.

38. National Committee for Clinical Laboratory Standards (NCCLS). 1979. Performance Standards for Antimicrobic Disc Susceptibility Tests. Second Edition, Villanova, PA. (ASM-2).

39. Novick, R. P. and C. Roth. 1968. Plasmid-linked Resistance to Inorganic Salts in Staphylococcus aureus. J. Bacteriol. $95(4): 1335-1342$.

40. Washington, II, J. A. 1974. The Agar-Dilution Technique. pp. 54-62. In: A. Balows (ed.), Current Techniques for Antibiotic Susceptibility Testing. Charles C. Thomas Publishing, Springfield, IL.

41. Barry, A. L. 1980. Procedure for Testing Antibiotics in Agar Media: Theoretical Considerations. pp. 1-23. In: Victor Lorian (ed.), Antibiotics in Laboratory Medicine. Williams \& Wilkins Co., Baltimore, MD.

42. Steers, E., E. L. Foltz and B. S. Graves. 1959. An Inocula Replicating Apparatus for Routine Testing of Bacterial Susceptibility to Antibiotics. Antibiot. Chemother. (Basel) IX (5) : 307-311.

43. NCCLS. 1980. Standard Methods for Dilution Antimicrobial Susceptibility Tests for Bacteria Which Grow Aerobically (Proposed Standard: PSM-7). Villanova, PA.

44. Ricketts, C. R. et. al. 1970. Mechanisms of Prophylaxis by Silver Compounds Against Infection of Burns. Br. Med. J $2: 444-446$.

45. Lapage, S. P. and W. R. Willcox. 1974. A Simple Method for Analyzing Binary Data. J. Gen. Microbiol. 85:376-380. 
46. Finland, M. 1971. Changes in Susceptibility of Selected Pathogenic Bacteria to Widely Used Antibiotics. Ann. NY Acad. Sci. 182: $5-20$.

47. Davies, J., M. Brzezinska and.R. Benveniste. 1971. R Factors: Biochemical Mechanisms of Resistance to Aminoglycoside Antibiotics. Ann. NY Acad. Sci. 182:226-233.

48. Davies, J, and R. Benveniste. 1973. Mechanisms of Antibiotic Resistance in Bacteria. Annu. Rev. Biochem. 42:471-506.

49. Silver, S. 1981. Mechanisms of Plasmid-Determined Resistance to Mercury, Cadmium and Arsenic in Staphylococcus aureus. In: J. Jeljaszewicz (ed.), Staphylococcal Infection, Zbl. Bakt. Suppl. 10. Gustav Vischer Verlag, NY.

50. Silver, S. 1981. Mechanisms of Plasmid-Determined Heavy Metal Resistances. (in press). In: S. B. Levy, R. C. Clowes and E. I. Koenig (eds.), Molecular Biology, Pathogenicity and Ecology of Bacterial Plasmids. Plenum Press, New York.

51. Nesbitt, Jr., R. U. and B. J. Sandmann. 1977. Solubility Studies of Silver sulfadiazine. I. Pharm. Sci. 66(4):519-522.

52. Carr, H. S., T. J. Wlodkowski and H. S. Rosenkranz. 1973. Silver Sulfadiazine: In Vitro Antibacterial Activity. Antimicrob. Agents Chemother. 4(5):585-587.

53. Fox Jr., C. I. and S. M. Modak. 1974. Mechanisms of Silver Sulfadiazine Action on Burn Wound Infections. Antimicrob. Agents Chemother. $5(6): 582-588$.

54. Whittenbury, R. 1965. The Differentiation of Streptococcus faecalis and.S. faecium. J. Gen. Microbiol. 38:279-287.

55. Feller, I., D. Tholen and R. G. Cornell. 1980. Improvements in Burn Care, 1965 to 1979. JAMA 224(18):2074-2078.

56. Roselle, G. A. and C. Watanakunakorn. 1979. Polymicrobial Bacteremia. JAMA $242(22): 2411-2413$.

57. Lynch, J. B. et. al. 1971. Changing Patterns of Mortality in Burns. Plast. Reconstr. Surg. $48(4): 329-334$.

58. Isenberg, H. D. and J. I. Berkman. 1971. The Role of DrugResistant and Drug-Selected Bacteria in Nosocomial Disease. Ann. NY Acad. Sci. 182:52-58. 